\title{
PRODUCTION OF QUINCE JAM WITH GINKGO BILOBA EXTRACT AS A PECTIN SUBSTITUTE: EFFECTS ON PHYSICOCHEMICAL, MICROBIOLOGICAL, RHEOLOGICAL AND SENSORY QUALITIES
}

\author{
Ahsen Rayman Ergün ${ }^{1 *}$, Yeliz Tekgül ${ }^{2}$ \\ ${ }^{1}$ Ege University, Engineering Faculty, Food Engineering Department, Bornova, İzmir, Turkey. \\ ${ }^{2}$ Aydın Adnan Menderes University, Köşk Vocatinoal School, Food Processing Departmant, Köşk, Aydın, \\ Turkey.
}

Received / Geliş: 03.06.2021; Accepted / Kabul: 30.09.2021; Published online / Online bask1: 06.10.2021

Rayman-Ergün, A., Tekgül, Y. (2021). Production of quince jam with Ginkgo biloba extract as a pectin substitute: effects on physicochemical, rheological and sensory qualities. GIDA (2021) 46 (5) 1301-1312 doi: $10.15237 /$ gida.GD21095.

Rayman-Ergün, A., Tekgül, Y. (2021). Pektin ikamesı olarak Ginkgo binloba özü ile ayva reçeli üretimi: fizikokimyasal, reolojik ve duyusal kalite üzerine etkileri. GIDA (2021) 46 (5) 1301-1312 doi: 10.15237/gida.GD21095

\section{ABSTRACT \\ In this study Ginkgo biloba leaf extract which is rich in phytochemical metabolites was used as a pectin substitute in quince jam. The extraction process was performed ultrasonically at $70^{\circ} \mathrm{C}$ with ethanol that gives the highest flavonoid content. The jam was produced with pectin in the traditional procedure and pectin- free jams were made using two different weight concentrations $(0.05 \%$ and $0.1 \%)$ of Ginkgo biloba extract and compared to the pectin group. Shear stress value decreased when Ginkgo biloba was used as a pectin substitute so the jam becomes softer. Phenolic content 170.09 (mg/g GAE), and antioxidant activity (1.80 $\mathrm{mM}$ Trolox $/ 100 \mathrm{~g}$ ) was found highest in the $0.1 \mathrm{~g}$ extract group. Lightness and yellowness increased with Ginkgo biloba compared to the pectin group. The jam sample with $0.1 \mathrm{~g}$ extract was preferred in sensory tests. Keywords: Ginkgo biloba, ultrasonic extraction, quince jam, antioxidant, rheological behaviour \\ PEKTİN İKAMESI OLARAK GINKGO BILOBA ÖZÜ İLE AYVA REÇELİ ÜRETİMİ: FİZİKOKİMYASAL, MİKROBİYOLOJİK, REOLOJİK VE DUYUSAL KALİTE ÜZERİNE ETKILLERİ} ÖZ

Bu çalışmada ayva reçelinde pektine ikame olarak fitokimyasallar açısından zengin olan Ginkgo biloba yaprağı ekstraktı kullanılmıştır. $70^{\circ} \mathrm{C}^{\prime}$ de etanol ile ultrasonik ekstraksiyon sonucu en yüksek flavonoid içeriğine ulaşılmış ve ekstraksiyon işlemi bu parametrede gerçekleştirilmiştir. Reçel geleneksel yöntemle pektin ile üretilmiş ve Ginkgo biloba ekstraktının iki farklı konsantrasyonunda (\%0.05 ve $\% 0.1$ ) pektinsiz üretilen reçel grubu geleneksel üretim grubu ile karşılaştırılmışır. Pektine ikame olarak Ginkgo biloba kullanıldığında reçelin kayma gerilimi değeri azalmış ve reçel daha yumuşak olmuştur. Fenolik madde içeriği 170.09 (mg/g GAE) ve antioksidan aktivite (1.80 mM Trolox/100g) $0.1 \mathrm{~g}$ ekstrakt grubunda en yüksek bulunmuştur. Pektin grubuna kıyasla Ginkgo biloba ile parlaklık ve sarılık değerlerinde artış saptanmıştır. Duyusal testlerde $0.1 \mathrm{~g}$ ekstrakt içeren reçel örneği tercih edilmiştir.

Anahtar kelimeler: Ginkgo biloba, ultrasonik ekstraksiyon, ayva reçeli, antioksidan, reolojik davranış

* Corresponding author / Yazışmalardan sorumlu yazar

(1): ahsenrayman@hotmail.com $\quad$ (D) : (+90) 2323113042

国: (+90) 2323114831

Ahsen Rayman Ergün; ORCID no; 0000-0003-0943-1950

Yeliz Tekgül; ORCID no: 0000-0001-8173-023X 


\section{INTRODUCTION}

Quince, (Cydonia oblonga Mill.) which belongs to the Rosaceae family, is a subtropical fruit grown in Europe and Mediterranean countries. Turkey is the country with the highest production rate of quince (189.251 tonnes) (TÜiK, 2020). Because of its hardness and sourness, it is not consumable when raw. Most of the harvested quince fruits are processed into jam, marmalade, liquor, jelly, and candy (Wojdylo et al. 2013).

Jam production is a traditional food preservation method. Home-made jam is prepared by evaporating fruit puree with sugar. Acid, pectin, and other ingredients (coloring, flavouring, preservatives) can be used in the commercial jam (Baker et al. 2005). According to the Codex standards, total soluble solids of jams should be at least 60\% (Anon 1981). High sugar content, low water activity, increasing acidity cause the shelf life of the jam to be extended (Garrido et al. 2015). Despite osmotic dehydration, some types of bacteria, mold, and yeast can survive in jams (Pascual \& Calderon, 2000). In order to prevent microbial activity, several researchers recommend the use of some plant extracts in jam. The addition of pomegranate, lemon, rosemary, and aloe vera extracts in jams increases the stability of the product during storage (Gómez et al. 2013, Kim 2005).

In the industrial manufacture of jam, adding approximately $0-10 \mathrm{~g} / \mathrm{kg}$ commercial pectin may be needed to provide constant gel strength (Vibhakara and Bawa 2006). Pectin is a heteropolysaccharide that is extracted from the plants' cell walls (Sulieman et al. 2013).

Citrus peels and apple pomace are mainly used as commercial pectin sources. There are also studies on the gelling characteristics of some fruit and vegetable powders (baobab, mango, ambarella, peach, pomegranate, sapodilla) that can be used as a substitute for commercial pectin in jam production (Koubala et al. 2012, Ndabikunze et al. 2011, Siddiqui et al. 2015).

Additionally, Ginkgo biloba (GB) contains many polysaccharides such as mannose, rhamnose, glucuronic acid, galacturonic acid, galactosamine, glucose, galactose, xylose, arabinose, and fucose similar to a standard monosaccharide content (mannose, glucosamine, ribose, rhamnose, glucuronic acid, galacturonic acid, galactosamine, glucose, galactose, xylose, arabinose, and fucose) (Chen et al., 2012; Fang et al., 2020). Owing to these contents it has the ability of gel making property.

Ginkgo biloba is a type of tree used in medicine (Chan et al. 2007). Clinical studies reveal that it is effective in the treatment of diseases such as cancer, diabetes, dementia, thrombosis, Alzheimer's, ischemic heart disease, hypertension (Birks et al. 2009, Vellas et al. 2012, Biggs et al. 2010, Brinkley et al. 2010, Kuller et al. 2010). It is consumed as a dietary supplement as it contains different phytochemical metabolites such as terpenoids, steroids, flavonoids, glycosides, alkaloids, and lignans (Mei et al. 2017, Su et al. 2009). Ginkgo biloba leaf polysaccharide has also been used as the reducing and stabilizing agent and also used in preparing candy and beverages (Fang et al., 2020). In addition, it is reported that Ginkgo biloba leaf extract shows antimicrobial activity against various pathogens because of its chemical structure (Yuan et al. 2019). There are several studies about quince jam quality (Ferreira et al. 2004, Silva et al. 2002).On the other hand, Ginkgo biloba food supplement has been studied, as well (Czigle et al. 2018, Fransen et al. 2010). However, to our knowledge, using Ginkgo biloba in jams has not been researched yet. The aim of this study was to research the effect of the addition of two different concentrations of Ginkgo biloba extract in quince jam, on the physicochemical (soluble solid content, $\mathrm{pH}$, acidity, color, total phenolic and antioxidant content), microbiological (osmophilic mold and yeast count), rheological and sensory properties (color, texture, odor, flavor, and general appeal).

\section{METHODS}

\section{Jam materials}

Fresh quince (Cydonia oblonga Mill.) samples were purchased from a market in Aydin (Turkey). Dried Ginkgo biloba leaves were obtained from 
Arpaş Arifoğlu Food Ind. (Istanbul, Turkey) and stored at $20{ }^{\circ} \mathrm{C}$ until extraction procedures.

\section{Chemicals}

Folin-Ciocalteu reagent and gallic acid were purchased from Merck Co. (Darmstadt, Germany). Citrus peel pectin (74\% degree of esterification), Trolox, were obtained from Sigma Chemical Co. (St. Louis, Mo, USA). All other reagents were at analytical grade.

\section{Extraction procedure}

Ginkgo biloba leaves were ground in a laboratorytype grinder (Sinbo-SCM 2934, Turkey). Three different solvents $(75 \%$ ethanol, $75 \%$ methanol and ultrapure water), and two different extraction parameters (15 and $30 \mathrm{~min}$ ) were tested for the total amount of phenolic and flavonoid contents.

$1 \mathrm{~g}$ sample was put in a flask and filled with extraction solvent $(75 \%$ ethanol) to $50 \mathrm{~mL}$. The extraction process was performed at $30^{\circ} \mathrm{C}$ for 30 min with an ultrasonic device (Sonorex Super RK-106, $35 \mathrm{kHz}, 480 \mathrm{~W}$, Germany). After the ultrasonic extraction, the slurry was transferred to falcon tubes and centrifuged at $4500 \mathrm{rpm}$ for 15 min with a centrifuge (Hettich EBA 21, Germany). The centrifuged samples were filtered. All extracts were stored at $4{ }^{\circ} \mathrm{C}$ (Akbulut et al., 2021).

\section{Jam production}

Quince jams were prepared according to the extra-traditional procedure taking into the limits in the Turkish Food Codex (Anon, 2010). The raw quinces were washed, peeled, and sliced. Fruits were boiled in hot water (4:1, weight: weight w/w) at $100{ }^{\circ} \mathrm{C}$ for $5 \mathrm{~min} .250 \mathrm{~g}$ of boiled fruit and $305.5 \mathrm{~g}$ of sugar were used to prepare quince jam. The boiled fruit and sugar were boiled in an open vessel. A pectin-free group was prepared as a control. The production of pectinfree jams was done using two different concentrations $(0.05 \%$ and $0.1 \%)$ of Ginkgo biloba extract and also a group was produced with commercial pectin $(0.8 \%)$. Citric acid solution $(10 \%$; w/v) was used to adjust the $\mathrm{pH}$ value to approximately 3 for all groups. The boiling was continued until the total soluble solids value reached $68^{\circ} \mathrm{Bx}$. A digital refractometer (MA871, Hanna Instruments Ltd, UK) was used to determine total soluble solids. Hot quince jam samples were poured into sterilized jars and kept in the refrigerator until analysis.

\section{Methods of analysis \\ $\mathrm{pH}$ measurement}

A digital $\mathrm{pH}$ meter (inoLab 7110, W'TW, Germany) was used to measure the $\mathrm{pH}$ values of quince jams.

\section{Titratable acidity analysis}

Quince jam samples were homogenized using a blender (Waring 8010S/G, Malaysia). $10 \mathrm{~g}$ sample was diluted with $100 \mathrm{ml}$ distilled water then filtered. The filtrate $(20 \mathrm{ml})$ was titrated with 0.1 $\mathrm{N} \mathrm{NaOH}$ (Cemeroğlu, 2010). Results were expressed as citric acid $\%(\mathrm{w} / \mathrm{g})$ according to the following equation (1).

Total titrable acidity (\%) $\frac{V * F * E * 100}{m}$

$\mathrm{V}$ : volume of the consumption

F: factor of the $\mathrm{NaOH}$

$\mathrm{m}$ : the amount of the sample $(\mathrm{g})$

E: the amount of equivalent acid

\section{Color analysis}

The color values of quince jams were obtained using a chromameter (CR-10, Konica Minolta, Japan). The device has been calibrated according to the standard white line $(\mathrm{Y}=93.9, \mathrm{x}=0.313$, $\mathrm{y}=0.321), L^{*}$ (bright), $a^{*}$ (red-green), and $b^{*}$ (blueyellow) values were measured (Zor and Şengül, 2020).

\section{Antioxidant activity analysis}

In order to determine the antioxidant activity and total phenolic content, the first samples were extracted. For this reason, $25 \mathrm{~mL}$ of methanol:water $(50: 50 \mathrm{v} / \mathrm{v})$ was added to the samples weighed $5 \mathrm{~g}$ in centrifuge tubes. After the treatment of 10 minutes in an ultrasonic water bath (Everest Ultrasonic, Turkey). After centrifugation for 20 minutes at $8500 \mathrm{rpm}$ and 4 ${ }^{\circ} \mathrm{C}$ in a centrifuge (Hettich Universal 320, Germany). The supernatant on the centrifuge tubes was collected and stored in glass bottles until analysis at $20^{\circ} \mathrm{C}$ (Şengul et al., 2018). 
The total antioxidant activity of jams was measured by the 2,2-Azino-bis-(3-ethylbenzothiazoline-6-sulfonic acid) (ABTS) assay (Re et al. 1999). ABTS + radical cation reduction capacities were expressed as $\%$ inhibition. The antioxidant capacity of samples was measured according to a calibration curve that was formed using Trolox at $734 \mathrm{~nm}$. Results were expressed as $\mathrm{mM}$ Trolox/100g.

\section{Total phenolic compound analysis}

The same extraction procedure was made before the analysis mentioned previously in the antioxidant activity analysis part. Total phenolic compound concentration was measured as stated in Singleton and Rossi (1965) using Folin \& Ciocalteau reagent. The absorbance was measured at $760 \mathrm{~nm}$. Various concentrations of gallic acid solution were used to plot a calibration curve. Results were expressed as $\mathrm{mg} / 100 \mathrm{~g}$ gallic acid equivalent (GAE).

\section{Microbiological analysis}

Jam samples were stored 15 days at two different temperatures $\left(4 \pm 2{ }^{\circ} \mathrm{C}\right.$ and $\left.20 \pm 2{ }^{\circ} \mathrm{C}\right)$ for following the microbiological growing (Randazzo et al., 2013; Rababah et al., 2014; Zor and Şengül, 2020). It was determined in previous researches that no longer growth was seen after 15 days. For microbiological analysis, $10 \mathrm{~g}$ samples were homogenized with a stomacher for $1 \mathrm{~min}$ after the addition of $90-\mathrm{ml}$ diluent. Malt Extract Agar (MEA, Merck, $\mathrm{pH}$ 5.4-5.8) containing 40\% sucrose was used to determine osmophilic mold and yeast counts. After the inoculation of plates using the pour plate technique, they were incubated at $25^{\circ} \mathrm{C}$ for $3-5$ days. At the end of the incubation period, mold and yeast colonies were counted (Pitt and Hocking, 2009).

\section{Rheological analysis}

The rheological measurements of quince jam samples were performed using a controlledviscometer (Brookfield LVDV-II, USA) with a spindle (S-25 and 31) and its rotational speed of $0.0-200 \mathrm{rpm}$ and between 0 and 100\% full-scale torques. During the rheological measurement, shear stress (SS), shear rate (SR), viscosity (cP), and $\%$ torque $(\mathrm{T})$ values were recorded for each rotational speed (rpm). The experiments were carried out in duplicate.

\section{Measuring sensory attributes}

The sensory test was performed with semi-trained 9 panelists. All samples were given at room temperature with coded in three-digit numbers randomly. The panelists scored the samples with a hedonic rating scale from 1 to 5 (1=like very much 2=like $3=$ like moderately $4=$ dislike $5=$ dislike very much) indicating increasing general appeal level in the 0.05 significance scale (Altug and Elmac1, 2011).

\section{Statistical analysis}

Statistical evaluation of data was performed with the software SPSS (version 20, SPSS Inc., Chicago, IL, USA). Duncan's multiple comparison test was used to determine the difference between means. The production was made in two replicates and all of the analyses were replicated 3 times.

\section{RESULTS}

\section{Determination of the extraction parameters}

Three different solvents ( $75 \%$ ethanol, $75 \%$ methanol, and ultrapure water) and two different extraction parameters (15 and $30 \mathrm{~min}$ ) were tested for the total amount of phenolic and flavonoid contents. The results were given in Table 1 . The highest phenolic content was found in methanol extraction. But the flavonoid extraction was highest with $75 \%$ ethanol. Ethanol which is also more suitable for human health (Karahan, 2017), was selected for ultrasound extraction. $30 \mathrm{~min}$ extraction process was completed optimally with ethanol.

\section{Evaluation of physical and chemical quality}

Soluble solid content, antioxidant activity, phenolic contents, acidity, $\mathrm{pH}$, and color values were measured and compared within groups after production (Table 2). Soluble solid contents were the same for all sample groups and suitable for the TS 4188 the standard of quince jam as $68 \%$ (Anon, 2010). The production was made until the same ${ }^{\circ}$ Brix value. 
Table 1. Total flavonoid and phenolic contents after extraction pretreatments.

\begin{tabular}{lccc}
\hline & $\begin{array}{c}\text { Extraction time } \\
(\mathrm{min})\end{array}$ & $\begin{array}{c}\text { Total phenolic } \\
\text { content } \\
(\mathrm{Mg} \mathrm{GAE} / \mathrm{L})\end{array}$ & $\begin{array}{c}\text { Total flavonoid content } \\
(\mathrm{Mg} \text { QE/L) }\end{array}$ \\
\hline$\% 75$ Ethanol & 15 & $545.36^{\mathrm{b}, \mathrm{e}}$ & $688.98^{\mathrm{a}, \mathrm{g}}$ \\
$\% 75$ Ethanol & 30 & $571.06^{2, \mathrm{~d}}$ & $756.78^{1, \mathrm{f}}$ \\
$\% 75$ Methanol & 15 & $585.99^{\mathrm{a}, \mathrm{e}}$ & $530.09^{\mathrm{b}, \mathrm{g}}$ \\
$\% 75$ Methanol & 30 & $611.90^{1, \mathrm{~d}}$ & $574.57^{2, \mathrm{f}}$ \\
Ultra Pure Water & 15 & $434.24 \mathrm{c,d}$ & $318.22^{\mathrm{c}, \mathrm{g}}$ \\
Ultra Pure Water & 30 & $433.42^{3, \mathrm{e}}$ & $373.31^{3, \mathrm{f}}$ \\
\hline
\end{tabular}

${ }^{a-c}$ symbolized the difference within the columns at different solvents for 15 min extraction time $(p<.05)$.

d-e symbolized the difference within the columns at different times for total phenolic content $(p<.05)$.

f-g symbolized the difference within the columns at different times for total flavonoid content $(p<.05)$.

${ }^{1-3}$ symbolized the difference within the columns at different solvents for 30 min extraction time $(p<.05)$.

GAE is referring to the Gallic acid equivalent.

$\mathrm{QE}$ is referring to Quercetin equivalent.

The acidity values were given in Table 2 and were significantly differ between each group $(\mathrm{P}<0.05)$. In this study, acidity values were increased when GB extract was used. Similar to this study, in jam processing, the effect of heat decreased $\mathrm{pH}$ values and increased acidity (Bekele et al., 2020; Rababah et al., 2012). This can be explained by the hydrolysis of the GB extract due to heat. Nakanishi (2005) reported that ginkgolides and bilobalides were the major constituents of GB extract. Ginkgolides were biosynthesized through the glyceraldehyde-pyruvate pathway. Ginkgolides were bitter taste and also volatile.

$\mathrm{pH}$ values were found as $3.05,3.3,3.12$, and 3.21 respectively for the groups of control, pectin, 0.05 $\mathrm{g}$, and $0.1 \mathrm{~g} \mathrm{~GB}$. In jam production $\mathrm{pH}$ value is needed to be between the 3.0-3.5 values for a targeted gel occurrence (Kiliç et al. 1987). Additionally, the TS 4188 standard of quince jam (Anon, 2010) prescribed that it should have a $\mathrm{pH}$ value of 2.8-3.6. $\mathrm{pH}$ and acidity values were found in previous researches as 3.13, 0.36\% (Zor and Şengül, 2020) and as 3.32-3.48, 0.21-0.39 g/100 $\mathrm{ml}$ (Yllmaz, 2007), respectively. These values were in agreement with the standard and also with our study. Total acids as citric (\%) were found as 0.30 0.41. It was reported by Roy et al. (2018), the $\mathrm{pH}$ values of jams ranged between 2.62 to 3.34 . $\mathrm{pH}$ was also effective on the color of the jam as mentioned in a study as the $\mathrm{pH}$ values were lower, the color values became higher and the color of the jam was pinker (Kuwada et al., 2013).

In this study, color values such as brightness were increased in the GB groups compared to the pectin group $(P \leq 0.05)$ parallel with the increase in the concentration of the GB extract. Redness decreased whereas yellowness $\left(b^{*}\right)$ increased. But there were no significant differences between the yellowness of control, pectin, and $0.05 \mathrm{~GB}$ group $(P<0.05)$. This could be due to the original color of the extract and during the heating process, the extract did not cause the browning and/or deterioration in the appearance of the jam. When the literature examined for quince jam it was seen that Zor and Şengül (2020) determined the $L^{*}, a^{*}$, and $b^{*}$ values as $35.91,8.20$ and 12.35 respectively for the quince jam. Wojdyło et al. (2013) detected the color values of the jams prepared from quince fruits as $L^{*}=50.7, a^{*}=0.1$, and $b^{*}$ as 18.2. They stated that the color values $L^{*}, a^{*}$, and $b^{*}$ were differed in mixed jam samples. They found no significant difference between the lightness of quince jam and jam with flowering quince. There are lots of studies about fortifying the jam with dietary fibres such as Igual et al. (2014), studied with the bamboo fibre and this makes the color 
of osmotic dehydration of grapefruit jams similar to the fresh ones. In agreement with this idea, Falcão et al. (2009) emphasized that the consumer preference changed with the color of food products and temperature changes and caused losses in this critical factor. The pectin was used in the traditional jam process for providing gel but needs high temperatures for gel-forming. So the color loss was seen at high temperatures.

They also explained these differences in the luminosity with the cooking and concentration. Maillard reactions and caramelization of sugars result in a dark product at long times and high temperatures. Differently, Roy et al. (2017) studied with pectin from pomelo peel in carrot jam found that color loss was lower in jam prepared with pomelo pectin than that made with commercial pectin, and the concentration of pectin was inversely changed with the color. They also associated this consequence with the variation in phenolics. Antioxidant activities were increased by the Ginkgo biloba extract significantly $(P>0.05)$ and found at most in the sample of 0.1 GB as 1.80 (mM Trolox/100g). This plant is known for its rich antimicrobial and antioxidant property.

Table 2. Quality characteristics of jams with different gelling agents

\begin{tabular}{|c|c|c|c|c|}
\hline \multirow[b]{2}{*}{ Quality parameters } & \multicolumn{4}{|c|}{ Sample groups } \\
\hline & Control & Pectin & $0.05 \mathrm{~GB}$ & $0.1 \mathrm{~GB}$ \\
\hline $\mathrm{pH}$ & $3.50 \pm 0.15^{\mathrm{a}}$ & $3.30 \pm 0.02^{\mathrm{a}}$ & $3.12 \pm 0.01^{\mathrm{a}}$ & $3.21 \pm 0.00^{\mathrm{b}}$ \\
\hline Acidity (\%) & $0.39 \pm 0.80^{\mathrm{a}}$ & $0.41 \pm 0.04^{a}$ & $0.46 \pm 0.02^{\mathrm{a}}$ & $0.57 \pm 0.02^{\mathrm{b}}$ \\
\hline$L^{*}$ & $48.00 \pm 0.46^{a}$ & $48.21 \pm 0.20^{a}$ & $49.53 \pm 0.12^{\mathrm{b}}$ & $54.68 \pm 0.08^{c}$ \\
\hline$a^{*}$ & $4.12 \pm 0.17^{a}$ & $4.07 \pm 0.09^{a}$ & $1.88 \pm 0.15^{\mathrm{b}}$ & $3.79 \pm 0.05^{c}$ \\
\hline$b^{*}$ & $27.03 \pm 0.93^{a}$ & $27.47 \pm 0.56^{a}$ & $28.61 \pm 0.77^{a}$ & $30.12 \pm 0.10^{\mathrm{b}}$ \\
\hline $\begin{array}{l}\text { Antioxidant Activity } \\
\text { (mM Trolox } / 100 \mathrm{~g})\end{array}$ & $0.49 \pm 0.50^{\mathrm{a}}$ & $0.47 \pm 0.00^{\mathrm{a}}$ & $0.85 \pm 0.01^{b}$ & $1.80 \pm 0.01^{\mathrm{c}}$ \\
\hline $\begin{array}{l}\text { Total Phenolic Compounds } \\
\left(\mathrm{mg} / \mathrm{kg} \mathrm{db}^{-1} \text { GAE }\right)\end{array}$ & $166.30 \pm 3.12^{a}$ & $173.00 \pm 2.09^{\mathrm{a}}$ & $497.02 \pm 7.90^{b}$ & $870.09 \pm 3.16^{c}$ \\
\hline
\end{tabular}

a-c Means within each line followed by a different letter are significantly different $(P<0.05)$

GAE: Gallic acid equivalent, GB: Gingko biloba

The antioxidant activity of sample groups with GB also increases in parallel with the increasing concentration of the extract as expected. Similarly, Maltaş (2011) reported that Ginkgo biloba is a good source for phenolics and hence for antioxidant compounds. Phenolic compounds were found as 166.3, 173, 497.02, and 870.09 $\mathrm{mg} / \mathrm{kg} \mathrm{db}^{-1} \mathrm{GAE}$ respectively for the jam samples produced as control, pectin, $0.05 \mathrm{~GB}$, and $0.1 \mathrm{~GB}$ groups. There was a statistical significance between the phenolic contents of GB and control groups $(P \leq 0.05)$. The increase was approximately 7 times between the pectin group and 0.05GB group. It is worth mentioning that this result is very important for the consumer's health. Phenolics have an important role in antioxidants which reduces the risk of many diseases by reducing oxidative stress (Slinkard and Singleton, 1977). It was previously stated that the total polyphenolic compounds in quince jam were $484.5 \mathrm{mg} / 100 \mathrm{~g}$. They indicated that the phenolic compounds in this sample contain flavan-3-ols mostly $(77.3 \%$ of total phenolic compounds), then proanthocyanidins with the ratio of $63.4 \%$, and at least $(11 \%$ and $7.8 \%$ of total phenolic compounds) hydroxycinnamic acids, especially neo chlorogenic and chlorogenic acid, respectively (Wojdyło et al., 2013). In jams prepared by Silva et al. (2004a), the content of phenolic compounds was found as $134.1 \mathrm{mg} / 100 \mathrm{~g}$ and $357.1 \mathrm{mg} / 100 \mathrm{~g}$ the jams were made from peeled and unpeeled quince fruits respectively. The traditional type of jams has ascorbic acid content as \% 3.88 whereas the ascorbic acid 
content was found $\% 2.16$ in the industrial type of jams.

\section{Evaluating steady-state and time-dependent rheology}

Viscoelastic properties of the products are crucial for conceiving their behavior during the process, storge and, consumption (Augusto et al., 2013). The consistency of jellies, marmalades, and jams had significance in the consumption. In this study, the effect of the addition of Ginkgo biloba to quince jam on rheological behavior was investigated. Rheological properties were evaluated and the experimental shear stress versus shear rate rheograms was determined in Figure 1. The shear rate was varied between 3.4 to $68 \mathrm{~s}^{-1}$. It was found that the samples showed nearer to Newtonian fluid (shear thinning) behavior whereas the pectin sample showed a pseudoplastic behaviour. The shear stress of the jams increased as the shear rate increased. Tiwari et al. (2016), informed in their study in detail how to decide the rheological behaviour of the food. The classification was made due to the flow curve (shear stress $\mathrm{v} / \mathrm{s}$ shear rate). If it is linear and passes through the origin is said to be Newtonian. When the flow curve either does not passes through origin or is non-linear, the material is said to be Non-Newtonian. Basu and Shviare (2013) stated that when the shear rate increases, apparent viscosity decreased confirming the nonNewtonian behavior of jam samples. Álvarez et al. (2006), studied different jams such as strawberry, raspberry, prunes, peach, and apricot and found non-newtonian pseudoplastic behaviour. Additionally, apparent viscosity and shear rate were evaluated. It was found that the apparent viscosity decreased as the rate of shear increased in Figure 1. The apparent viscosity of the jams increased with the increase of extract concentration $(P<0.05)$. Moreover, viscosities were decreased from pectin to $0.05 \mathrm{~GB}$ sample with the increase in $\mathrm{pH}$ values. Falcão et al. (2009), performed the apparent viscosity values as a function of increasing shear rate for the different jams. They decided that the jams were non-Newtonian fluids and showed pseudoplastic rheology, they indicated that an important characteristic of the apparent viscosity/shear rate ratio is the occurrence of hysteresis. Tiwari et al. (2016) observed that the curve was close to each other and the loop area was small enough to neglect the thixotropy and they found the jackfruit jam as viscoplastic. Furthermore, Kayacier and Dogan (2006) increase in the shear rate decreases the apparent viscosity.

These results were confirmed with Basu and Shivhare (2013), produced mango jam and detected a decrease in apparent viscosity with increasing shear rate demonstrated the nonNewtonian behavior. Barbieri et al. (2018) also explained the situation why the shear stress rheogram begins far from the initial point of the shear stress/shear rate plot and is concaved downwards. This was because of yield stress during the flow of a material which provides a cross linked structure or other interactive structure that should be corrupted before the flow begin with the convenient rate (Canet et al., 2005, Sun and Gunasekaran, 2009).

Shear stress versus time for the groups was given in Figure 1. They also mentioned that shear stress decreased depending on time (Basu and Shivhare, 2013). Similarly, Sabanc1 et al. (2016), showed that the time, temperature, and shear rate affected the rheological properties of koumiss. Falcao et al. (2009), studied with the jam model system and they observed that when the temperature increased, the consistency also increased. In addition, linear viscoelastic properties and viscosities increased with pectin concentration (Díaz-Ocampo et al., 2014).

\section{Evaluation of microbiological quality}

Jam samples were stored 15 days at two different temperatures $\left(4 \pm 2{ }^{\circ} \mathrm{C}\right.$ and $\left.20 \pm 2{ }^{\circ} \mathrm{C}\right)$ for following the microbiological growing (Randazzo et al., 2013; Rababah et al., 2014). It was determined in previous researches that no longer growth was seen after 15 days. At the beginning of the storage (zero-day) and the end of 15 days, osmophilic mold and yeast counts were below the detection limit of $<1.0 \log \mathrm{CFU} / \mathrm{g}$ of the samples. 


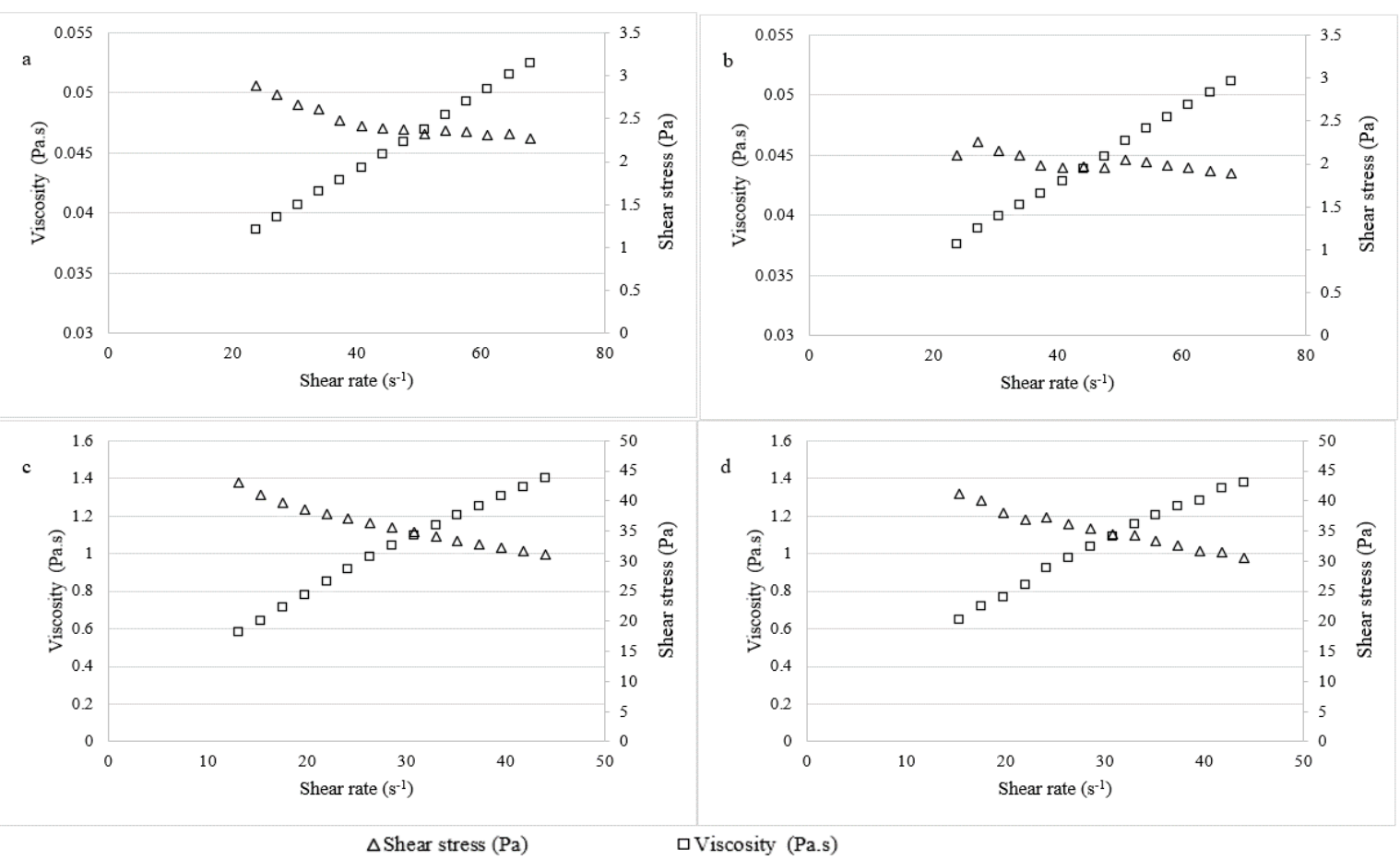

Figure 1. Rheograms of quince jam groups as $0.1 \mathrm{~GB}, 0.05 \mathrm{~GB}$, control, and pectin.

* Graphs a, b, c, and d show the rheograms of quince jam groups as 0.1GB, 0.05 GB, control and pectin respectively.

Likewise, the microbial load in stored jackfruit jam was evaluated by Tiwari et al. (2016) found that samples were stable on storage and no colonies were detected at the end of 16 months at $7^{\circ} \mathrm{C}$. It was already denoted that the low $\mathrm{pH}$ and high sugar content are critical for the quality during storage, inhibition of the growth of molds and yeasts and assure satisfactory setting of the marmalade such as the marmalade produced by fluted pumpkin fruit was found stable with no mold count at $52-56^{\circ} \mathrm{C}$ (Egbekun et al., 1998). Ferreira et al., (2004) supported this situation by presenting a total number of yeast and mould in quince jam higher than $10 \mathrm{CFU} / \mathrm{g}$ due to a lower Brix value lower than $63 \%$.

\section{Evaluation of sensory quality}

Quince jams were tested for color, texture, odor, flavor, and general appeal 1 to 5 via to liking level. Figure 2 shows the average scores for the jam samples. 0.1 GB extract sample was liked mostly by the panelists in terms of the color, texture, flavor, and general appeal properties. An only control sample was preferred regarding the general appeal. This demonstrated that panelists can consume easily this new product. The kinds and amount of constituents change the food texture and the consumers can easily notice these differences when tasting with a mouthfull. In previous researches, a hedonic test was conducted generally to jam samples and it was reported that panelists give importance to color firstly rather than other attributes such as Garrido et al. (2015) who studied with apple jelly stated that consumers give attention to taste and color rather than textural properties.

They scored between 3.6-6.2 in the 9 scales hedonic test. In another study, Basu and Shivhare (2013) investigated the properties of mango jam. They obtained that increased pectin concentration and acidity caused hardness and these groups were not preferred. They made a hedonic test similar to our study and the overall acceptability scores increased by increasing $\mathrm{pH}$ and sugar concentration. Basu et al. (2013) researched the effect of sorbitol alternatives to sucrose and found that the scores in the sensory 
evaluation were higher for the sorbitol group than the scores for the jam manufactured with sucrose. Pérez-Herreraa et al., (2020) reported that adding the dietary fiber to jam caused an increase in gel strength and this reduced the acceptance. They suggested that it is useful to optimize the amount of constituents such as acid and sugar to provide acceptable jams with Physalis spp. fruit that also includes the seeds. As concluded sensory property of a new or fortified product was changeable with the amount of added material and optimization of these factors was important.

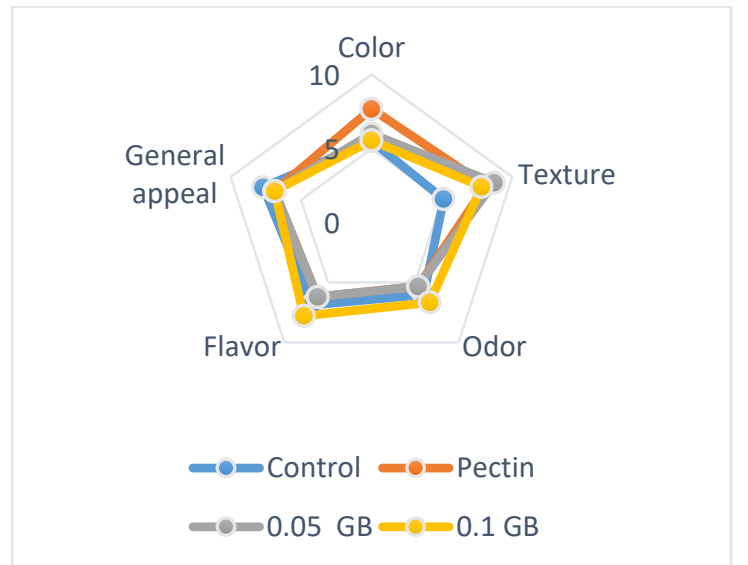

Figure 2: Average scores of the panelists for hedonic test on the quince jam groups as $0.1 \mathrm{~GB}$, $0.05 \mathrm{~GB}$, control, and pectin

\section{CONCLUSION}

In this study, quince jam was produced by two different concentrations of Ginkgo biloba extract as a pectin substitute. Phenolic contents and antioxidant activity were significantly increased in parallel with the concentration of extract $(\mathrm{P} \leq$ 0.05). Rheological properties also differed from pectin. The panelists prefer the jam sample with $0.1 \mathrm{~g} \mathrm{~GB}$ extracts rather than the pectin added jam. The preferred jam sample with $0.1 \mathrm{~g}$ Ginkgo biloba extract by the panelists demonstrated that this extract can be used alternatively also for improving the sensory quality together with its benefits in chemical, physical, and microbiological attributes. In future studies, the synergistic effect of GB extract with other functional plant extracts on the quality of jams with fruits and vegetables can be researched.

\section{CONFLICT OF INTEREST}

There is no conflict of interest between the authors.

\section{AUTHOR CONTRIBUTION}

Ahsen RAYMAN ERGÜN, provided the production, analysis, evaluation of the results and writing of the manuscript. Yeliz TEKGÜL, planned the research, provided the evaluation of the analysis, and writing the manuscript. All authors contributed to the article and approved the submitted version.

\section{REFERENCES}

Altuğ Onoğur, T., Elmac1, Y. (2011). Sensory evaluation in foods. İzmir, Turkey: Sidaş.

Akbulut İ., Gürbüz, E., Ergün A. R., Baysal, T. (2021). Drying of Apricots Treated with Ginkgo biloba Plant Extract and Determination of the Quality Properties. Journal of Advanced Research in Natural and Applied Sciences. 7 (1): 145-159.

Álvarez, E., Cancela, Ma, Maceiras, R. (2006). Effect of Temperature on Rheological Properties of Different Jams. International Journal of Food Properties, 9(1), 135-146.

Anon. (2010). Quince Jam Standard, Ts 4188, Turkish Standardization Institute, Ankara.

Augusto, P., Ibarz, A., Cristianini, M. (2013). Effect of High Pressure Homogenization (Hph) on The Rheological Properties of Tomato Juice: Creep and Recovery Behaviours. Food Research International, 54: 169-176

Anon. (1981). Codex Standard for Jams (Fruit Preserves) and Jellies Codex Alimentarius Commission, Rome, Italy.

Baker, R., Berry, N., Hui, Y., Barrett, D. (2005).Food Preserves and Jams (Seconded.). Boca Raton, Fl, Usa: Crc Press 113-125.

Barbieri, S., Petkowicz, C., Godoy, R., Azeredo, H., Franco C., Silveira, J. (2018). Food Chemistry. Pulp and Jam of Gabiroba (Campomanesia Xanthocarpa Berg): Characterization and Rheological Properties, 263, 292-299.

Basu, S., Shivhare, U. (2013). Rheological, Textural, Microstructural, And Sensory 
Properties of Sorbitol-Substituted Mango Jam. Food Bioprocess Technol, 6:1401-1413.

Basu, S, Shivhare, U., Singh T. (2013). Effect of Substitution of Stevioside And Sucralose On Rheological, Spectral, Color And Microstructural Characteristics of Mango Jam. Journal Of Food Engineering, 114(4), 465-476.

Biggs, M., Sorkin, B., Nahin, R., Kuller, L., Fitzpatrick, A. (2010). Ginkgo Biloba and Risk of Cancer: Secondary Analysis of The Ginkgo Evaluation of Memory (Gem) Study. Pharmacoepidemiol Drug Saf. 19,694-698.

Birks, J., Grimley, E. J. (2009). Ginkgo biloba for Cognitive Impairment and Dementia. Cochrane Database. Syst Rev,1: Cd003120.

Brinkley, T., Lovato, J., Arnold, A., Furberg, C., Burke, G., Nahin, R., Lopez, O., Yasar, S., Williamson, J. (2010). Effect of Ginkgo Biloba on Blood Pressure and Incidence of Hypertension in Elderly Men and Women. Am J Hypertens. 23, 528-533.

Canet, W., Alvarez, M., Fernández, C., Luna, P. (2005). Comparisons of Methods for Measuring Yield Stresses in Potato Puree: Effect of Temperature and Freezing. Journal of Food Engineering, 68(2), 143-153.

Cemeroğlu, B. (2010). Food Analysis. Food Technology Association Press. Ankara (In Turkish).

Chan, P., Xia, Q., Fu, P. (2007). Ginkgo biloba Leave Extract: Biological, Medicinal, And Toxicological Effects. J Environ Sci Health C Environ Carcinog Ecotoxicol Rev, 25, 211-244.

Chan, S., Choo, W., Young, D., Loh, X. (2017). Pectin as a Rheology Modifier: Origin, Structure, Commercial Production And Rheology. Carbohydrate Polymers, 161, 118-139.

Chen, J, Zhang, T., Jiang, B., Mu, W., Miao J. M. (2012). Characterization and antioxidant activity of Ginkgo biloba exocarp polysaccharides .Carbohydrate Polymers 87:40-45.

Czigle, S., Tóth, J., Jedlinszki, N., HáznagyRadnai, E., Csupor, D., Tekel’ová, D. (2018) Ginkgo biloba Food Supplements on The European Market - Adulteration Patterns
Revealed by Quality Control of Selected Samples. Planta Med, 84: 475-482.

Díaz-Ocampo, R., Sánchez, R., Franco, J. (2014). Rheology of Commercial and Model Borojó Jam Formulations. International Journal of Food Properties, 17(4), 791-805.

Egbekun, M., Nda-Suleiman, E., Akınyeye, O. (1998). Utilization Of fluted Pumpkin Fruit (Telfairia Occidentalis) in Marmalade Manufacturing. Plant Foods for Human Nutrition, 52:171-176.

Falcão, A., Chaves, E., Falcão, L., Gauche, C., Barreto., P., Bordignon-Luiz, M. (2009). Ciênc. Tecnl. Aliment., Campinas. Rheological Behavior and Color Stability of Anthocyanins from Merlot (Vitis Vinifera L.) and Bordô (Vitis Labrusca L.) Grapes in A Jam Model System 29(4):857-862.

Fang, J., Wang, Z., Wang, P., Wang, P. (2020). Extraction, structure and bioactivities of the polysaccharides from Ginkgo biloba: A review International Journal of Biological Macromolecules 162: 1897-1905.

Ferreira, I., Pestana, N., Alves, M., Mota, F., Reu, C., Cunha, S., Oliveira, M.. (2004). Quince jam Quality: Microbiological, Physicochemical and Sensory Evaluation. Food Control, 15: 291-295.

Fransen, H.P., Pelgrom, S.M.G.J., Stewart-Knox, B., de Kaste, D., Verhagen, H. (2010) Assessment of health claims, content, and safety of herbal supplements containing Ginkgo biloba. Food \& Nutrition Research, 54:1.

Garrido, J., Lozano, J., Genovese, D. (2015). Effect of Formulation Variables on Rheology, Texture, Colour, and Acceptability of Apple Jelly: Modelling and Optimization. Lwt - Food Science and Technology, 62: 325-332.

Gómez, F., Igual, M., Camacho, M., Paga, N. (2013). Effect of The Addition of Plant Extracts on The Microbiota of Minimally Processed Strawberry Jam and Its Physicochemical and Sensorial Properties. Cyta - Journal of Food, 11(2): 171-178.

Heidi, P., Fransen, Sylvia M., Pelgrom, B., Stewart-Knox, D., Hans, V. (2010). Assessment of Health Claims, Content, and Safety of Herbal 
Supplements Containing Ginkgo biloba. Food \& Nutrition Research, 54(1): 5221.

Igual, M., Contreras, C., Martınez-Navarrete, N. (2014). Colour and Rheological Properties of Non-Conventional Grapefruit Jams: Instrumental and Sensory. Lwt- Food Science and Technology, 56(1): 200-206.

Kayacier, A., Doğan, M. (2006). Rheological Properties of Some Gums-Salep Mixed Solutions. Journal of Food Engineering, 72(3): 261-265.

Kilıç, O., Başoğlu, F., Çopur, U., Etel, M. (1987) Fruit and Vegetable Processing Technology. Uludağ University Faculty of Agriculture Lecture Notes, Bursa, Turkey.

Kim, Y. (2005). Antimicrobial Activity of Yacon K-23 and Manufacture of Functional Yacon Jam. Korean J. Food Sc1. Technology 37(6):1035-1038.

Koubala, B., Kansci, G., Garnier, C., Ralet, M., Thibault, J. (2012). Mango (Mangifera Indica) And Ambarella (Spondias Cytherea) Peel Extracted Pectins Improve Viscoelastic Properties of Derived Jams. African Journal of Food, Agriculture, Nutrition and Development, 12(3): 6200-6212.

Kuller, L.H., Ives, D.G., Fitzpatrick, A.L., Carlson, M.C., Mercado, C., Lopez, O.L., Burke, G.L., Furberg, C.D., Dekosky, S.T. (2010). Ginkgo Evaluation of Memory Study I. Does Ginkgo biloba Reduce The Risk of Cardiovascular Events. Circ Cardiovasc Qual Outcomes, 3: 41-47.

Kuwada, H., Jibu, Y., Teramoto, A., Fuchigami, M., Nakamurab, K., Tabuchib, M., Teramotoc, A., Ishiia, K., Kımuraa, Y., Fuchigamia, M. (2010). Changes in Texture, Structure and Pectin of Peach During Pressurization, Heating or Processing of High-Pressure-Induced and HeatInduced Jam. Journal of Food Science and Technology,

Maltaş, E. (2011). Analysis of Ginkgo biloba by Chemical and Molecular Methods. Ph. D. Thesis. Selcuk University Institute of Science, KonyaTurkey.

Mei, N., Guo, X., Ren, Z., Kobayashi, D., Wada, K., Guo, L. (2017). Review of Ginkgo bilobaInduced Toxicity, From Experimental Studies to
Human Case Reports. Journal of Environmental Science and Health, Part C. 35(1): 1-28.

Nakanishi, K. (2005). Terpene Trilactones From Ginkgo biloba: From Ancient Times to the 21st Century. Bioorg Med Chem,1 13 (17): 4987-5000.

Ndabikunze, B., Masambu, B., Tiisekwa, B., IssaZacharia, A. (2011). The Production of Jam from Indigenous Fruits Using Baobab (Adansonia Digitata L.) Powder as a Substitute for Commercial Pectin. African Journal of Food Science, 5(3):168-175.

Pascual, M., Calderón, V. (2000). Microbiología Alimentaria. Metodología Analítica para Alimentos y Bebidas (2nd ed.) Editorial Díaz de Santos S.A, Madrid, España.

Pérez-Herrera, A., Martínez-Gutiérrez, G., LeónMartínez, F., Sánchez-Medina, M. (2020). The Effect of The Presence of Seeds on The Nutraceutical, Sensory and Rheological Properties of Physalis Spp. Fruits Jam: A Comparative Analysis. Food Chem, 302, 125-141.

Pitt, J., Hocking, A.D. (2009). The ecology of fungal food spoilage, in: Hocking, Fungi and Food Spoilage. CSIRO-Division of Food ResearchSydney. Academic Press Australia, 5-18.

Rababah, T. M., Al-Mahasneh, M., Yang, W., Feng, H., Ereifej, K., Kllani, I., Ishmais M. A. 2014. Effect of Jam Processing and Storage On Phytochemicals and Physiochemical Properties of Cherry at Different Temperatures. Journal of Food Processing and Preservation. Journal of Food Processing and Preservation 38: 247-254.

Randazzo, C. L., Pitino, L., Licciardello, F., Muratore, G., Caggia, C. 2013. Survival of Lactobacillus rhamnosus probiotic strains in peach jam during storage at different temperatures. Food Sci. Technol, Campinas, 33(4): 652-659.

Re, R., Pellegrini, N., Proteggente, A., Pannala, A., Yang, M., Rice-Evans, C. (1999). Antioxidant Activity Applying an Improved Abts Radical Cation Decolorization Assay. Free Radical Biology\&Medicine, 26(9-10): 1231-1237.

Roy, M., Alam, M., Abu Saeid, A., Das, B., Mia, M., Rahman, A., Eun, J., Ahmed, M. (2018). Extraction and Characterization of Pectin from 
Pomelo Peel and Its Impact on Nutritional Properties of Carrot Jam During Storage. J Food Process Preserv, 42: E13411.

Siddiqui, N., Azhar, I., Tarar, O., Masood, S., Mahmood, Z. (2015). Influence of Pectin Concentrations on Physicochemical and Sensory Qualities of Jams. World Journal of Pharmacy and Pharmaceutical Sciences, 4(6): 68-77.

Silva, B., Andrade, P., Mendes, G., Seabra, R., Ferreira, M. (2002). Study of The, Organic Acids Composition of Quince (Cydonia Oblonga Miller) Fruit and Jam. J. Agric. Food Chem, 50: 2313-2317.

Silva, B., Andrade, P., Valentao, P., Ferreres, F., Seabra, R., Ferreira, M. (2004). Quince (Cydonia Oblonga Miller) Fruit (Pulp, Peel and Seed) and Jam: Antioxidant Activity. Journal of Agricultural and Food Chemistry, 52(15): 4705-4712.

Singleton, V., Rossi, J. (1965). Colorimetry of Total Phenolics with PhosphomolybdicPhosphotungstic Acid Reagents. American Journal of Enology and Viticulture, 16: 144-158.

Slinkard, K., Singleton, V. (1977). Total Phenol Analyses: Automationand Comparison with Manual Methods. American Journal of Enologyand Viticulture, 28: 49-55.

Su, S. L., Duan, J. A., Tang, Y. P., Zhang, X., Yu, L., Jiang, F. R., Zhou, W., Luo, D. \& Ding A. W. (2009). Jiangsu Key Laboratory to Tcm Formulae Research, Nanjing University of Chinese Medicine, Nanjing, P.R. China. Planta Medica, 75(4): 351- 355.

Sulieman, A., Khodari, K., Salih, Z. (2013). Extraction of Pectin from Lemon and Orange Fruits Peels and Its Utilization in Jam Making. International Journal of Food Science and Nutrition Engineering, 3(5): 81-84.

Sun, A., Gunasekaran, S. (2009). Yield Stress in Foods: Measurements and Applications. International Journal of Food Properties, 12: 70101.

Şengül, M., Topdaş, E.F., Doğan, H., Serencam, H. (2018). Some Physical and Chemical Properties, Antioxidant Activities and Phenolic
Profiles of Different Marmalades Traditionally Produced in Artvin, Turkey. Academic Food Journal. 16(1): 51-59.

Tiwari, A., Vidyarthi, A., Nigam, V., Hassan, M. (2016). Study F Rheological Properties and Storage Life F Ripe Jackfruit Products: Jam and Jelly. Asian Jr Of Microbiol. Biotech. Env. Sc., 18(2): 475-482.

Vellas, B.,Coley, N., Ousset,P.,Berrut,G., DartıguesJ., Dubois, B., Grandjean, H., Pasquier, F.Piette, F., Robert, P., Touchon, J., Garnier, P., Mathiexfortunet, H., Andrieu, S. (2012). Guidage. Study G. Long-Term Use of Standardised Ginkgo biloba Extract for The Prevention of Alzheimer's Disease (Guidage): A Randomised PlaceboControlled Trial. Lancet Neurol, 11: 851-859.

Vibhakara, H.S., Bawa, A.S. (2006). Manufacturing jams and jellies. In Hui YH (ed) Handbook of fruits and fruits processing, 189204.

Wojdyło, A., Oszmiański, J., Teleszko, M., Łętowska, S. A (2013). Composition and quantification of major polyphenolic compounds, antioxidant activity and colour properties of quince and mixed quince jams, International Journal of Food Sciences and Nutrition, 64:6, 749-756, DOI: 10.3109/09637486.2013.793297"

Y1lmaz, M. (2007). Suitability of Quince Fruits of Various Cultivars Grown on The Agricultural Experimental Station of ozantı for Preserve Production. Çukurova University,

Institute of Science, Master's Thesis, Adana, Turkey.

Yuan, Z., Tian, Y., He, F., Zhou, H. (2019). Endophytes from Ginkgo biloba and Their Secondary Metabolites. Chin Med, 14-51.

Zor, M., Şengül, M. (2020). Some Physicochemical Properties and Antioxidant Activity of Quince (Cydonia Oblonga Miller) Fruit and Quince Jam Stored in Different Packaging and At Different Temperatures. Atatürk Univ. J. Of Agricultural Faculty, 51 (1): 97-108. 